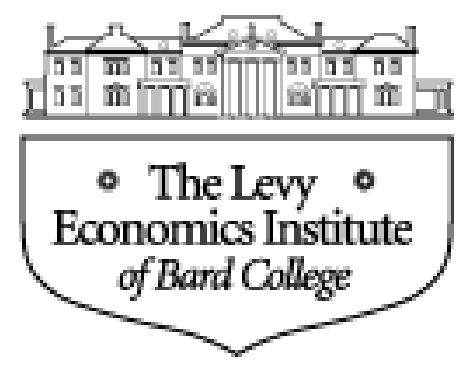

Working Paper No. 470

\title{
Retiree Health Benefit Coverage and Retirement
}

By

James Marton

and

Stephen A. Woodbury

August 2006

James Marton is an assistant professor in the Martin School of Public Policy \& Administration, University of Kentucky, Lexington, KY 40506, (859) 257-4387 mailto:marton@uky.edu

Stephen A. Woodbury is a professor in the Department of Economics, Michigan State University, East Lansing, MI 48824, (517) 355-4587

mailto:woodbur2@msu.edu

and senior economist at the W.E. Upjohn Institute for Employment Research, 300 South Westnedge Ave., Kalamazoo, MI 49007, (269) 343-5541

mailto:woodbury@upjohninstitute.org

The Levy Economics Institute Working Paper Collection presents research in progress by

Levy Institute scholars and conference participants. The purpose of the series is to disseminate ideas to and elicit comments from academics and professionals.

The Levy Economics Institute of Bard College, founded in 1986, is a nonprofit, nonpartisan, independently funded research organization devoted to public service. Through scholarship and economic research it generates viable, effective public policy responses to important economic problems that profoundly affect the quality of life in the United States and abroad.

\author{
The Levy Economics Institute \\ P.O. Box 5000 \\ Annandale-on-Hudson, NY 12504-5000 \\ http://www.levy.org
}

Copyright (C The Levy Economics Institute 2006 All rights reserved. 


\begin{abstract}
Employer-provided health benefits for workers who retire before age 65 has fallen over the last decade. We examine a cohort of male workers from the Health and Retirement Survey to explore the dynamics of retiree health benefits and the relationship between retiree health benefits and retirement behavior. A better understanding of this relationship is important to the policy debate over the best way to increase health coverage for older Americans without reducing work incentives. Concerning the dynamics at work, we find that, between 1992 and 1996, 24 percent of full-time workers who had retiree health benefits lost their coverage, while 15 percent of full-time workers who lacked coverage gained it. Also, of the full-time employed men who were covered by retiree health benefits in 1992 and had retired by 1996, 3 percent were uninsured, and 15 percent were covered by health insurance other than employer-provided insurance. On the relationship between retiree health benefits and retirement, we find that workers with retiree benefits were 29 to 55 percent more likely to retire than those without. We also find that workers who are eligible for retiree health benefits tend to take advantage of them when they are relatively young.
\end{abstract}

JEL classifications: J26, J32, J33, I18, M52

Keywords: Health insurance, employee benefits, retirement, elderly, employment, retiree health benefits 


\section{RETIREE HEALTH BENEFITS AND RETIREMENT}

Labor markets and health insurance are closely linked in the United States because many employers provide health insurance to both current and retired workers. Economists and policy analysts have paid much attention to the reasons for and consequences of employer provision of health insurance to current employees—see, for example, Rosen (2000) for a review and discussion — but retiree health benefits have received far less attention, at least in part because data on them have been scarce.

Nevertheless, retiree health benefits raise important issues for public policy. Offers of employer-provided retiree benefits—especially offers to early retirees—have become less common in recent years (see section 1). ${ }^{1}$ By definition, early retirees are not yet eligible for Medicare and may not be able to afford private coverage. Moreover, their expected health care expenses are larger than those of younger workers. If society values the consumption of health care coverage by early retirees, employer-provided retiree coverage is likely to be a public policy concern.

Any number of public policies could increase the health insurance coverage of early retirees. For example, Medicare could be extended to early retirees, or new incentives could be created (or mandates adopted) for employers to offer additional retiree health coverage. However, given the link between health markets and the labor market, such policies could have the unintended consequence of increasing the incentive to retire early in order to take advantage of the expanded health coverage. The extent to which this is a problem depends on the strength of the relationship between the availability of retiree health benefits and labor supply (in this case, retirement).

Our main goal in this paper is to add to the evidence on the effects of retiree health benefits on retirement. We do this by examining data from the Health and Retirement Study (HRS), a major longitudinal survey sponsored by the National Institute

\footnotetext{
${ }^{1}$ Because most retirees are eligible for Medicare at age 65, employer-provided retiree health benefits are of two kinds - first, coverage for early retirees (those younger than 65), which often continues the health insurance a worker had while employed until age 65; second, coverage for the Medicare eligible (those 65 or older), which supplements Medicare so that retirees have comprehensive health insurance. Alternatives to employer-provided retiree health benefits do exist, but they are usually more expensive or less generous than employer-provided health insurance. For example, early retirees may buy private health insurance, and retirees age 65 and older may buy Medigap insurance or enroll in Medicare Advantage (Medicare Part C, a private plan administered through Medicare).
} 
of Aging and conducted by the University of Michigan. Unlike early work using the HRS, we use information on the availability of retiree health benefits and pensions in more than one year; in particular, we examine a pair of two-year retirement transitions, 1992 to 1994 and 1994 to 1996, for a sample of men who were employed full-time in 1992, and allow for changes in retiree health benefits and pensions between 1992 and 1994. Also, because labor force participation of a spouse may well be important to a man's decision to retire, we add variables to the model capturing the employment of each man's wife. Finally, we include in the models a control for self-reported health status in order to obtain additional evidence on the correlation between health and retirement decisions.

The next section describes the extent to which workers are covered by retiree health benefits, examines trends in that coverage over time, and discusses reasons for the trends. We also follow a panel of men from the HRS over time, illustrating their retirement behavior and changes in their health benefit coverage using probability trees. We then describe the existing literature on health benefit coverage and retirement and discuss how our analysis contributes to this literature. The following sections describe the HRS data we use, the retirement models we estimate, and the results of estimation. We conclude with a summary of our findings, a discussion of policy implications, and some suggestions for extending the analysis.

\section{TRENDS AND CHANGES IN RETIREE HEALTH COVERAGE}

How widespread are retiree health benefits, and how has retiree health coverage changed over time? Figures 1 through 4 show, for various types of employers, trends in the percentage who offer retiree health benefits to their workers. The data underlying the figures come from the Insurance Component of the Medical Expenditure Panel Survey (MEPS-IC), a survey of employers conducted by the Agency for Health Care Research and Quality of the U.S. Department of Health and Human Services. Figure 1 shows that about 20 percent of private employers offered retiree health benefits in 1997, but this had 
fallen to about 13 percent by 2003. Figure 2 shows that large employers are far more likely than private employers, taken as a whole, to offer retiree health benefits.

A comparison of Figures 1 and 3 shows that government employers are more likely to offer retiree health benefits than are private employers. Despite this difference, offers of retiree health benefits among public employers are also becoming less common (Figure 3). The trend appears to be confined to local government employers, however, as the percentage of state government employers that offer retiree health benefits has increased since 1997 (Figure 4). In 2003, 88 percent or more of state government employers offered retiree health benefits to their employees.

The above figures pertain to the percentage of employers offering retiree health benefits. But what percentage of workers is covered by retiree health benefits? Fronstin (2005) has generated estimates from the Survey of Income and Program Participation (SIPP) showing that in 1997, about 50 percent of workers aged 45 to 64 expected to receive retiree health benefits upon retirement. This percentage had dropped to roughly 47 percent by 2002. For males, the percentages are slightly higher—57 percent in 1997 and 51 percent in 2002. These latter percentages are comparable to those for the HRS sample we examine in this paper. What is especially interesting about Fronstin's estimates, though, is that they far exceed the percentage of retired individuals who report actually receiving retiree health benefits (Fronstin 2005). In 1997, 39 percent of early retirees and 28 percent of Medicare-eligible retirees reported that they were receiving retiree health benefits, and these figures had fallen to 28 percent and 26 percent by 2002 . It is reasonable to infer that many workers who expect retiree health benefits do not receive them.

Fronstin (2001, 2005) and Schieber (2004) attribute the decline in retiree health coverage largely to Financial Accounting Statement No. 106 (FAS 106)—“Employers’ Accounting for Postretirement Benefits Other Than Pension”-which the Financial Accounting Standards Board approved in December 1990. FAS 106 requires employers to treat promised retiree health benefits as financial liabilities in their financial statement starting with fiscal years after December 15, 1992. The result was reconsideration of promised retiree health benefits and, in many cases, reduction or elimination of those promises. 
Two more recent factors may also lead employers to curtail early retiree health benefits. First, a federal court ruling in 2000 held that it is discriminatory for an employer to provide early retirees more generous health benefits than those provided by the employer and Medicare (combined) to retirees age 65 and older (U.S. Government Accountability Office 2005). As Moon (2005) points out, this ruling and subsequent rules will make it harder for employers to provide health benefits to early retirees. Second, the new Medicare prescription drug benefit (Medicare Part D) could induce employers to cut retiree health benefits on the grounds that the government now offers adequate coverage at age 65. As Moon (2005) again points out, for employers who are planning to reduce or eliminate retiree health benefits, the Medicare drug benefit offers an excuse for opting out.

On the other hand, it is also possible that employers have reduced retiree health benefits out of a recognition that the baby-boom generation, which makes up a disproportionate part of the labor force, is aging and may be difficult to replace. The Economist (2006) has quoted human resource managers who say they are concerned that "When the baby-boomer generation retires, many companies will find out too late that a career's worth of experience has walked out the door, leaving insufficient talent to fill the void.” It follows that reducing retiree health benefits could be part of a deliberate strategy to slow the loss of older skilled workers to retirement.

We can gain further insight into changes in retiree health benefit coverage by tabulating the longitudinal data on workers from the HRS that we analyze more extensively below. To illustrate how access to retiree health coverage changes over time for a given sample of workers, we created two probability trees-Figures 5 and 6. Both figures start with a baseline sample of 3,172 men who were 51 to 61 years old and employed full-time 1992. The tree shows that 1,775 of these men (56 percent) had access to retiree health benefits in 1992, whereas 1,397 (44 percent) did not. Branches of the tree to the right of the dashed line show how many of these workers remained in the sample, had retired, remained employed full-time, or had moved to some other labor force state (employed part-time, unemployed, partly retired, disabled, or not in the labor force) by 1994 (Figure 5) or 1996 (Figure 6). Continuing to the right, further branches subdivide retired workers by their health insurance status (employer-provided health insurance, 
other health insurance, or uninsured), employed full-time workers by whether they continued to have access to retiree health benefits (RHB or no RHB), and men in other labor force states by their health insurance status (insured or uninsured) in 1994 or 1996.

Four main findings emerge from Figures 5 and 6. First, some workers who had retiree health benefits in 1992 no longer had them in 1994 or 1996. Figure 5 shows that, of the full-time employed men who were covered by retiree health benefits in 1992, 75 percent $(1,338 / 1,775)$ were still employed full-time in 1994, and 94 percent of the latter $(1,263 / 1,338)$ were still covered by retiree health benefits; however, nearly 6 percent $(75 / 1,338)$ of those who remained employed full-time had lost their retiree health benefits. It follows that 4 percent $(75 / 1,775)$ of the employed full-time men who were covered by retiree health benefits in 1992 had lost that coverage by 1994. Figure 6 shows that by 1996, only 56 percent of full-time covered men $(1,001 / 1,775)$ remained employed full-time, and only 58 percent of the latter $(580 / 1,001)$ were still covered by retiree health benefits. That is, of the 1,775 employed full-time men who were covered by retiree health benefits in 1992, 24 percent $(421 / 1,775)$ had lost retiree health benefit coverage by 1996 .

Why did so many workers lose retiree health benefits between 1992 and 1996 compared with 1992 to 1994? A significant part of the explanation may be that the HRS question on retiree health benefits differed between 1994 and 1996. The 1994 questionnaire asked HRS respondents whether their employer-provided health insurance was “available to people who retire” (question R8 of the 1994 survey). This question is ambiguous in at least two ways. First, a respondent could interpret it to pertain to either early retiree benefits or Medicare-eligible retiree benefits. Second, a respondent could interpret it to apply either to himself or to any other worker. The 1996 questionnaire asked respondents a more specific question - whether the respondent's employerprovided health insurance could be continued up to the age of 65 if he or she left the employer at the time of the interview (questions R34 and R35 of the 1996 survey). This question is restricted to the availability of early retiree benefits (rather than all retiree benefits) to the respondent (rather than any worker), so by definition it will elicit fewer positive responses than the 1994 question. It could well be that retiree health benefit offers dropped between 1994 and 1996, but the drop is likely to be exaggerated by comparing Figures 5 and 6. 
A second finding from Figures 5 and 6 is that some workers who lacked retiree benefits in 1992 had gained them by 1994 or 1996. Figure 5 shows that of the full-time employed men who lacked retiree health benefits in 1992, 72 percent $(1,005 / 1,397)$ were still employed full-time in 1994. Although 89 percent of the latter $(889 / 1,005)$ still lacked retiree health benefits, 12 percent $(116 / 1,005)$ had gained them. So 8 percent $(116 / 1,397)$ of the employed full-time men who lacked retiree health benefits in 1992 had gained coverage by 1994. Figure 6 shows that by 1996, 58 percent of full-time men without retiree health benefits $(809 / 1,397)$ remained employed full-time, and 74 percent of the latter (601/809) still lacked retiree health benefits; however, 26 percent (208/809) had gained coverage. That is, 15 percent $(208 / 1,397)$ of the employed full-time men who lacked retiree health benefits in 1992 had gained coverage by 1996. The finding suggests that as older workers increase their job tenure, they thereby become eligible for retiree health benefits.

Taken together, these first two findings indicate that retiree health coverage of a given worker does change over time, which suggests, in turn, the importance of allowing retiree health coverage to be a time-varying covariate in empirical models of retirement.

Third, some workers who reported having retiree health benefits in 1992, and who had retired by 1994 or 1996, did not have employer-provided health benefits in retirement. For example, Figure 6 shows that of the full-time employed men who were covered by retiree health benefits in 1992, 17 percent $(300 / 1,775)$ had retired by 1996 , and 82 percent of the latter (245/300) were receiving employer-provided retiree health benefits; however, 15 percent (45/300) were receiving other health insurance, and 3 percent (10/300) were uninsured. Although the percentage uninsured is quite small, the data displayed in Figures 5 and 6 give some longitudinal support to Fronstin's (2005) inference that "workers are more likely to expect retiree health benefits than retirees are actually likely to have those benefits."

Fourth, workers with retiree health benefits are more likely to retire than those without. Consider first the changes between 1992 and 1994. Whereas 9 percent of workers with retiree health benefits had retired by 1994 (and more than 90 percent of these were covered by employer-provided health benefits), less than 5 percent of workers who lacked retiree health benefits in 1992 had retired by 1994 (and only 38 percent of 
these had employer-provided health insurance). Changes between 1992 and 1994 tell a similar story: 17 percent of workers with retiree health benefits had retired by 1996, but only 10 percent of workers who lacked retiree health benefits in 1992 had retired by 1996. These figures give a first hint that retiree health benefits are related to earlier retirement.

\section{RETIREE HEALTH BENEFITS AND RETIREMENT: EXISTING RESEARCH}

Reductions in retiree health benefit coverage could lead government to respond by expanding Medicare or by regulating retiree benefits. In the absence of a government response, reductions in the availability of retiree health coverage could lead workers to change their labor supply behavior and work more or longer, because if they do not, they or their dependents will not be covered by health insurance.

Much public discussion in recent decades has suggested that a government response to declining retiree health benefits would be appropriate. Efforts to create universal health insurance coverage - through a single payer or some other meanswould obviously eliminate the problem implied by declining employer-provided retiree coverage. Government provision of health insurance would, in turn, have other consequences-workers who might otherwise continue working would retire because they would not need to work in order to maintain health insurance coverage. It follows that estimates of workers' labor supply response to retiree health benefits constitute an important part of the debate over government provision of retiree health benefits.

Much empirical research has investigated the effects of pensions, social security, and assets on the decision to retire, but relatively little research has examined the impact of health insurance coverage on retirement. ${ }^{2}$ Previous research has used data from the Retirement History Survey, conducted mainly during the 1970s (Rust and Phelan 1997),

\footnotetext{
${ }^{2}$ See Gruber and Madrian (2004) and Madrian (2006) for more complete reviews of the literature and additional background.
} 
the Survey of Income and Program Participation (Karoly and Rogowski 1994; Madrian 1994), the Current Population Survey (Gruber and Madrian 1995), and the National Medical Expenditure Survey (Madrian 1994). These studies uniformly conclude that availability of retiree health benefits (or continuation coverage, in the case of Gruber and Madrian) significantly increases the probability that an older worker will retire.

Hurd and McGarry (1993), Rogowski and Karoly (2000), and Blau and Gilleskie (2001) examine the relationship between retirement (or retirement expectations, in the case of Hurd and McGarry) and retiree health benefits using the Health and Retirement Study (HRS). The HRS has the unique advantage of being longitudinal and including questions on both retirement and the availability of retiree health benefits. As a result, studies based on these data are among the most convincing in this literature. Hurd and McGarry (1993) examine Wave 1 (1992) of the HRS and find that workers eligible to receive retiree health benefits that are partly or fully paid by the employer are significantly less likely than other workers to report that they expect to work past age 62 . Rogowski and Karoly (2000) and Blau and Gilleskie (2001) each take advantage of two waves of the HRS and find that workers with an offer of retiree health benefits are significantly more likely to retire than workers without. Rogowski and Karoly find that workers with retiree health benefits in 1992 were about 11 percentage points more likely to be retired in 1996 than those without. Blau and Gilleskie examine the transition to retirement between 1992 and 1994 and find that retiree health benefits increased the probability of retirement by 2 to 6 percentage points, depending on the extent to which retirees share in the cost of those benefits.

\section{EMPIRICAL MODEL AND DATA}

Both Rogowski and Karoly (2000) and Blau and Gilleskie (2001) leave open three issues that we explore here. First, they use observations on retiree health benefit coverage, pension coverage, and other variables in 1992 (Wave 1 of the HRS) to predict labor force participation 1994 (Wave 2) or 1996 (Wave 3). However, as seen in Figures 5 and 6, 
retiree health coverage is not constant for each worker but varies over time. Accordingly, in the estimates below, we allow the availability of retiree health benefits and pensions to vary from year to year. Second, a small amount of literature has examined the effect of one spouse's labor supply behavior on the other's labor supply (for example, Buchmueller and Valletta 1999, Wellington and Cobb-Clark 2000, and Olson 2000), so we add to the model variables capturing the employment of each man's wife. Third, because health is such an important factor in people's retirement decisions, we add to the list of health indicators each individual's self-reported health status. Our aim in making these changes is to check whether estimates of the impact of retiree health benefits on retirement are sensitive to changes in model specification.

We estimate the correlation between retiree health coverage and retirement over three time periods (1992-1994, 1994-1996, and 1992-1996) for a sample of men in the HRS born between 1931 and 1941 who were working full-time (at least 35 hours per week) as of 1992. ${ }^{3}$ The retirement decision between 1992 and 1994 is conditioned on health benefit and pension coverage in 1992, whereas the retirement decision between 1994 and 1996 is conditioned on health benefit and pension coverage in 1994. For comparison, we also estimate a four-year retirement transition, between 1992 and 1996, in which we condition only on health benefit and pension coverage in 1992.

Specifically, we estimate three probit models of the conditional probability that individual $i$ (working in 1992 or 1994) will be retired in a subsequent year (1994 or 1996):

$$
\begin{aligned}
& \operatorname{Pr}\left(\text { retired }_{i, 1994}=1 \mid \bullet\right)=F\left[\beta_{0}+\beta_{1}\left(\text { rhb }_{i, 1992}\right)+\beta_{2}\left(\text { pension }_{i, 1992}\right)+\beta_{3}\left(\text { health }_{i, 992}\right)+\right. \\
& \left.\beta_{4}\left(\text { spouse }_{i, 1992}\right)+\beta_{5}\left(X_{i, 1992}\right)\right] \\
& \operatorname{Pr}\left(\text { retired }_{i, 1996}=1 \mid \bullet\right)=F\left[\beta_{0}+\beta_{1}\left(\text { rhb }_{i, 1994}\right)+\beta_{2}\left(\text { pension }_{i, 1994}\right)+\beta_{3} \text { (health }_{i, 1994}\right)+ \\
& \left.\left.\quad \beta_{4} \text { spous }_{i, 1994}\right)+\beta_{5}\left(X_{i, 1994}\right)\right]
\end{aligned}
$$

\footnotetext{
${ }^{3}$ For the empirical analysis, we started with the RAND HRS Data file, Version F, which is a simplified longitudinal data set based on the HRS data. See St. Clair et al. (2006).
} 


$$
\begin{gathered}
\operatorname{Pr}\left(\text { retired }_{i, 1996}=1 \mid \bullet\right)=F\left[\beta_{0}+\beta_{1}\left(\text { rhb }_{i, 1992}\right)+\beta_{2}\left(\text { pension }_{i, 1992}\right)+\beta_{3}\left(\text { health }_{i, 1992}\right)+\right. \\
\left.\left.\beta_{4} \text { spouse }_{i, 1992}\right)+\beta_{5}\left(X_{i, 1992}\right)\right]
\end{gathered}
$$

In these probits, $r h b_{i t}$ denotes a set of dummies indicating whether worker $i$ was offered retiree health benefits in year $t$ (either 1992 or 1994); pension $i t$ is a set of indicators of whether worker $i$ was included in a pension plan (or plans) in year $t$; health $h_{i t}$ is a set of variables modeling the health of the worker in year $t$; spouse $_{i t}$ is a set of variables indicating whether the worker was married and whether his spouse was working in year $t$; and $X_{i t}$ is set of demographic variables. We specify these retirement equations as probits ( $F$ denotes the standard normal cumulative density), but linear probability models would serve just as well.

The sample starts with the 3,172 men ages 51 to 61 and employed full-time in 1992 (Wave 1) from the HRS. Over the subsequent four years, some men left the study (due to death or for other reasons), some retired, others continued to work full-time, and still others moved to part-time work, unemployment, partial retirement, disability, or left the labor force (the “other” category). Figure 7 illustrates these transitions. In 1994, 307 men left the study, so 2,865 men remained for estimating equation 1. Of these, 226 (8 percent) had retired by 1994. Between 1994 and 1996 another 183 left the sample, so 2,146 men remained to estimate equation 2. Of these, 228 (11 percent) had retired by 1996. The four-year retirement transition modeled by equation 3 is not shown in Figure 7, but between 1992 and 1996, a net total of 446 men left the study, so 2,726 remain to contribute to the estimation of equation 3. Of these, 449 (16 percent) had retired by 1996.

Table 1 displays sample means of the independent variables included in the models. The first column gives means of the "starting sample" — that is, the 3,172 men in the HRS who were employed full-time and 51-61 years old in 1992. The second and third columns show sample means of the "transition samples"-that is, the samples used to estimate equations 1 and 2. Comparison of the columns suggests that attrition results in samples of men who are less likely to have health insurance, less likely to be covered by a pension, and less likely to be married. Although the attrition does appear to be nonrandom, it does not appear severe enough to make attrition bias a serious concern. 
We model coverage by retiree health benefits $\left(r h b_{i t}\right)$ in year $t$ using a set of four mutually exclusive dummy variables:

- a dummy equal to 1 if the worker had employer-provided health insurance (EHI) but no offer of retiree health benefits ${ }^{4}$ (this is the reference category)

- a dummy equal to 1 if the worker had $\mathrm{EHI}$ and would receive health benefits if he retired

- a dummy equal to 1 if the worker had no EHI but was covered by some other type of health insurance

- a dummy equal to 1 if the worker had no health insurance coverage

As mentioned earlier, Fronstin (2005) found that roughly 57 percent of men ages 45-64 reported being covered by retiree health benefits in the 1997 SIPP, so the percentages of workers covered by retiree health benefits in the HRS samples we are using (between 56 and 60 percent) seem reasonable. Note that the percentages are somewhat higher for the 1992-1994 and 1994-1996 subsamples than for the starting sample.

A second set of dummies (pension ${ }_{i t}$, again mutually exclusive) models whether the worker was included in a pension plan or tax-deferred savings plan through his work in year $t$ :

- a dummy equal to 1 if the worker was not included in any pension plan or didn't know whether he was included (the reference category)

- a dummy equal to 1 if the worker was included in one or more defined contribution pension plans (but not included in any defined benefit plans)

- a dummy equal to 1 if the worker was included in one or more defined benefit pension plans (but no defined contribution plans)

- a dummy equal to 1 if the worker was included in both a defined contribution and a defined benefit pension plan

- a dummy equal to 1 if the worker said he was included in a pension plan but didn't know the type

\footnotetext{
${ }^{4}$ As discussed earlier, the 1992 and 1994 question reads, "Is the health insurance plan [that currently covers you] available to people who retire?” The 1996 and later waves of the HRS ask explicitly whether the respondent's health benefit plan would cover him if he retired before age 65.
} 
Nearly two-fifths of this sample was not covered by any employer-sponsored pension plan in 1992, typical of the population of working men in 1992.

Rogowski and Karoly (2000) included two variables to capture each worker's health status (health ${ }_{i t}$ ) in year $t$. The first is body mass index (BMI) in year $t$-weight in kilograms divided by height in meters squared - which has come to be widely used in the development literature as a measure of maximum physical capacity. The second is a dummy equal to 1 for workers who report having two or more chronic health conditions in year $t$, such as high blood pressure, diabetes, cancer, chronic lung disease, heart disease, stroke, or arthritis. The latter is only a rough indicator of a respondent's health, in part because it does not distinguish more serious from less serious conditions; however, limitations of the HRS make it difficult to construct a more telling health indicator based on a respondent's report of specific illnesses. Accordingly, we add to the model a dummy variable equal to 1 for respondents who report being in fair or poor health in year $t$.

Because the labor force status of a spouse is likely to be important to a man's decision to retire, we add to the model a set of dummies capturing the employment status of each man's wife in year $t$ :

- a dummy equal to 1 if the worker was not married (the reference category)

- a dummy equal to 1 if the worker was married to a woman working full-time

- a dummy equal to 1 if the worker was married to a woman working part-time

- a dummy equal to 1 if the worker was married to a woman who does not work (is unemployed, partly retired, retired, disabled, or not in the labor force)

Because labor supply decisions by couples are likely to be joint, we are concerned that this set of indicators is endogenous. This is a difficult issue, and the literature on health insurance and labor supply (cited above) has not addressed it. We include these variables to see whether estimates of the impact of retiree health benefits are sensitive to their inclusion or exclusion, and leave the endogeneity of spousal labor supply to future work.

The demographic controls included in the model $\left(X_{i t}\right)$ are age in 1992, an indicator equal to 1 for nonwhites, and years of schooling. Like Rogowski and Karoly (2000), we also include a variable indicating the length of time between wave interviews because that time varies across respondents. 


\section{EMPIRICAL FINDINGS}

Table 2 displays estimates of the probit models described above, with one panel for each model. Each panel gives probit $\beta \mathrm{s}$, P-values, marginal effects, and marginal effects relative to the base probability of retirement. (Each marginal effect is the expected percentage point change in retirement probability from a one-unit change in the independent variable at the sample mean.)

The key variable in each model is the indicator of employer-provided health insurance with retiree health benefit coverage ("has EHI and RHB"). The relationship between retiree health benefits and retirement is strong and statistically significant in each model. A worker with retiree health benefits in 1992 was 4 percentage points more likely to be retired in 1994 than was a comparable worker who had employer-provided health benefits but no retiree health benefits (1992-1994 model). This is a 55 percent increase in the baseline probability of retirement between 1992 and 1994 of 8 percent. Also, a worker with retiree health benefits in 1994 was 3 percentage points more likely to be retired in 1996 than a comparable worker who had no retiree health benefits (19941996 model)—a 29 percent increase in the baseline retirement probability between 1994 and 1996.

It follows that the relationship between retiree health benefits and retirement was stronger between 1992 and 1994 than between 1994 and 1996. This is a key finding. During 1992-1994, the cohort we are analyzing was younger than those between 19941996. The stronger relationship between retiree health benefit offers and retirement during 1992-1994 than during 1994-1996 suggests that workers with retiree health benefits tend to take advantage of those benefits when they are relatively young. This makes sense because retiree health benefits are more valuable to a worker at age 55 than at age 65-the younger worker receives the benefit over more years. To a worker eligible for retiree health benefits, each year of delayed retirement represents a year of lost benefits. As a result, we would expect the impact of retiree health benefits on retirement to fall as workers approach age 65. An important implication is that retiree health benefits are likely to be expensive precisely because they are more likely to be accepted by 
workers who are younger and further from Medicare eligibility. It is hardly surprising, then, that employers have been trimming their offers of retiree health benefits.

The 1994-1996 model differs from earlier retiree health benefit models estimated with the HRS because it updates the observations of retiree health benefits and other independent variables. For comparison, the 1992-1996 model estimates the probability of retirement in 1996 using only explanatory variables from 1992. That model suggests that a worker with retiree health benefits in 1992 was 7 percentage points more likely to be retired in 1996 than a comparable worker without retiree health benefits (1992-1996 model) — a 41 percent increase in the baseline retirement probability between 1992 and 1996 (16 percent). Although the finding is consistent with the findings from the separate 1992-1994 and 1994-1996 models, it masks the main finding from the separate models - that the relationship between retiree health benefits and retirement was stronger in the 1992-1994 transition-when the workers in the sample were younger (than in the 1994-1996 transition).

Rogowski and Karoly (2000) estimate a model similar to Table 2’s 1992-1996 model and find a marginal effect of retiree coverage of 11 percentage pointsrepresenting a 68 percent increase in their baseline probability of retirementsubstantially larger than our estimate. Why the difference? We believe the main factor is that Rogowski and Karoly used the alpha release of the HRS Wave 3 data, whereas we use the final release of the Wave 3 data, as further cleaned by RAND. We end up with a larger sample than theirs (2,726 vs. 2,638), more retirees (449 vs. 422), and a slightly higher baseline retirement probability (16.5 percent vs. 16.0 percent) over the four years. A related point is that Rogowski and Karoly's coding of the retiree health benefit and pension indicators may differ from ours (which is based on RAND's coding in the RAND HRS data). Because Rogowski and Karoly do not report sample descriptive statistics, it is difficult to know how our sorting of workers into different retiree health benefit and pension categories differs from theirs. ${ }^{5}$

\footnotetext{
${ }^{5}$ Two obvious differences between Rogowski and Karoly’s specification and ours do not seem to underlie the difference in estimated impact of retiree health benefits. First, Rogowski and Karoly included a dummy variable indicating whether a worker was married, whereas we included a set of indicators of the employment status of each worker's spouse. However, we have estimated the model with a dummy variable for married replacing the spouse employment status indicators, and the results (not reported) are essentially similar. Second, Rogowski and Karoly controlled for the cost sharing associated with retiree
} 
Table 2 also suggests that workers covered by a defined benefit pension in 1992 were 5 percentage points more likely to be retired in 1994 than those with no pension. Workers with both defined benefit and defined contribution pensions in 1992 were 4 percentage points more likely to be retired in 1994 than those without. These represent increases of 58 percent and 47 percent in the baseline probability of retirement between 1992 and 1994. The effects of pension coverage in 1994 on the probability of being retired in 1996 are even stronger, which suggests that this cohort of workers became more likely to accept a defined benefits pension as it aged. In striking contrast, workers covered by defined contribution pensions were no more likely to retire than were those with no pension. These findings make sense because defined benefit pensions tend to be structured so as to induce workers to retire between ages 62 and 65, whereas defined contribution pensions do not create strong retirement incentives (Lazear 1998). Because the cohort of men we are analyzing was 51 to 61 in 1992, it makes sense that the impact of a defined benefit pension on retirement would increase in later years (that is, as the cohort aged and the bulk of the cohort drew closer to age 62).

The models also include a measure of self-reported fair or poor health ("reports fair or poor health”), in addition to the body mass index and chronic conditions health indicators included by Rogowski and Karoly (2000). Fair or poor health is statistically significant in all three models_-men who report fair or poor health are between 3 and 7 percentage points more likely to be retired two to four years in the future than men who do not report fair or poor health. Body mass index is not significant in any of the models, and the indicator of multiple chronic conditions is significant only in the 1992-1994 model. (The latter suggests that having two or more chronic conditions in 1992 leads to a 30 percent increase in the baseline probability of retirement in 1994.)

The relationship between spousal labor supply and retirement is quite strong and suggests the importance of including spousal labor supply variables in retirement models. Men who had a full-time or part-time working wife in 1992 were 5 percentage points less likely to be retired in 1994 than were men who were not married. This represents a 60

health benefits, whereas we have not. We omitted cost sharing because HRS data on cost sharing are omitted from the RAND HRS Data file we are using. However, in a draft of this paper, we used the original HRS data, included cost sharing indicators, and like Rogowski and Karoly, found them to have little impact on retirement probabilities. The finding is surprising in light of other findings on the relationship between health insurance costs and decisions to retire (Johnson, Davidoff, and Perese 2003). 
percent drop in the baseline probability of retirement. The relationship between marriage to a full-time working spouse and retirement is smaller, but still statistically significant, for the 1994-1996 retirement transition. (The relationship between marriage to a parttime working spouse and retirement is insignificant for 1994-1996.) The findings are consistent with the idea that couples make decisions about retirement jointly—men and women with working spouses try to time retirement so as to retire at the same time as their spouse (Hamermesh 2002).

An important caveat applies to all the above estimates-they should not be interpreted causally. Although the findings do suggest that retiree health benefits cause earlier retirement, as we would expect, it is likely that workers who would like to retire before age 65 choose (or self-select into) jobs that offer retiree health benefits. If so, this self-selection would lead to upward-biased estimates of the causal effect of retiree health benefits on retirement - workers who are covered by retiree health benefits would have retired somewhat earlier even if they were not eligible for those benefits. Without further efforts to identify the true relationship between retiree health benefits and retirement, we cannot say anything about the size of this bias, but the issue is ripe for future research.

\section{SUMMARY, IMPLICATIONS, AND EXTENSIONS}

Paul Fronstin (2001, 2005) has shown clearly that during the last decade, fewer employers have offered retiree health benefits, and fewer workers have been covered by such benefits. Because early retiree health benefits provide a bridge to Medicare for dislocated workers in their 50s and early 60s, the decline of retiree health benefits leaves an increasing number of older workers vulnerable to loss of health insurance if they lose their job. However, past evidence, which we reconfirm here, suggests that retiree health benefits also induce workers to retire earlier than they would otherwise. Intentionally or not, retiree health benefits draw experienced and productive workers out of the labor force. 
In this paper, we have used data from the Health and Retirement Study to extend past work on retiree health benefits in three main ways. First, we develop a descriptive analysis of retiree health benefit coverage that compares the coverage of workers in 1992 with their coverage two and four years later. The analysis, summarized in two probability trees (Figures 5 and 6), shows the following:

- Of the full-time employed workers who had retiree health benefits in 1992, 4 percent had lost those benefits by 1992, and 24 percent had lost them by 1996 .

- Of the full-time employed workers who lacked retiree health benefits in 1992, 8 percent had gained them by 1994, and 15 percent had gained them by 1996.

- It follows that retiree health coverage of a given worker changes over time, so it may be important to account for such changes in formulating empirical models of retirement.

- Some full-time employed workers who thought they had retiree health benefits in 1992, and who had retired by 1994 or 1996, did not have employer-provided health benefits in retirement. Of the full-time employed men who were covered by retiree health benefits in 1992 and had retired by 1994, 4 percent were uninsured, and 5 percent were covered by health insurance other than employerprovided insurance.

The analysis is limited by changes in key survey questions between the 1994 and 1996 waves of the HRS, and we believe that further work with post-1996 HRS waves would be useful.

Second, in modeling the relationship between retiree health benefits and retirement, we have analyzed two separate two-year transitions in which the explanatory variables are updated for the second transition. The approach is a simplified survival analysis or event history analysis with time-varying covariates, and it allows us to observe different impacts of retiree health benefits on retirement as the cohort of workers ages. It contrasts with the approach taken in earlier work, where a single two- or fouryear transition is analyzed. The main findings can be summarized simply: 
- For the 1992-1994 transition, workers with retiree health benefits were 4 percentage points more likely to retire than those without-a 55 percent increase in the retirement probability.

- For the 1994-1996 transition, workers with retiree health benefits were 3 percentage points more likely to retire than those without-a 29 percent increase in the retirement probability.

We infer that this cohort of workers was most likely to accept retiree health benefits when they were relatively young, then grew less likely to do so as they aged. The implications are twofold. From a modeling perspective, the findings suggest the importance of examining repeated transitions and accounting for changes over time in the explanatory variables. From a policy perspective, the findings are important because they suggest that workers who are eligible for retiree health benefits tend to take advantage of them when they are young. This makes sense because retiree health benefits accepted when a worker is younger yield a benefit for longer and hence are more valuable. The implication, though, is that retiree health benefits represent an expensive benefit that tends to induce experienced workers with several remaining productive years to retire. Policies that create additional retiree health coverage need to account for the reduction in labor supply that may be an unintended consequence of such policies.

Third, we have attempted to improve on the previous literature by including the employment status of each worker's spouse in the retirement models. The findings suggest strongly that men with a full-time working spouse are less likely to retire than men who are not married. This suggests that husbands and wives views each other's leisure time as complementary; hence, couples time their retirements to coincide. Including spouse's employment status does not seem to appreciably change the estimated relationship between retiree health benefits and retirement (see note 5 above).

At least three extensions of the work presented here would be useful. First, it would clearly be interesting to examine additional two-year retirement transitions by adding more recent HRS waves to the analysis. Second, it may well be possible to do a better job of controlling for the health of the workers in the sample by including different health indicators from the HRS that we have not exploited. Third, in recent years the 
HRS has added cohorts of "War Babies" (born between 1942 and 1947) and "Early Baby Boomers" (born between 1948 and 1953). Examining the behavior of these younger cohorts and comparing it with the behavior of the original HRS sample could have important implications for public policy. We hope to pursue these extensions in future work. 


\section{REFERENCES}

Blau, David M. and Donna B. Gilleskie. 2001. "Retiree Health Insurance and Labor Force Behavior of Older Men in the 1990s." Review of Economic and Statistics 83 (February): 64-80.

Buchmueller, Thomas C. and Robert G. Valletta. 1999. "The Effect of Health Insurance on Married Female Labor Supply.” Journal of Human Resources 34(1): 42-71.

The Economist. 2006. “Special Report: The Aging Workforce.” February 18: 65-67.

Fronstin, Paul. 2005. "The Impact of the Erosion of Retiree Health Benefits on Workers and Retirees.” Employee Benefit Research Institute Issue Brief No. 279, March.

_. 2001. "Retiree Health Benefits: Trends and Outlook.” Employee Benefit Research Institute Issue Brief No. 236, August.

Gruber, Jonathan and Brigitte C. Madrian. 2004. "Health Insurance, Labor Supply and Job Mobility: A Critical Review of the Literature.” In Health Policy and the Uninsured. Catherine G. McLaughlin, ed.. Washington, D.C.: Urban Institute Press.

. 1995. "Health Insurance Availability and the Retirement Decision.” American Economic Review 85(September): 938-948.

Hamermesh, Daniel S. 2002. “Timing, Togetherness, and Time Windfalls.” Journal of Populations Economics 15(4): 601-623.

Hurd, Michael and Kathleen McGarry. 1993. "The Relationship between Job Characteristics and Retirement Behavior.” National Bureau of Economic Research Working Paper No. 4558, December.

Institute for Social Research, University of Michigan. 2006. The Health and Retirement Study. Full documentation and data available at $<$ http://hrsonline.isr.umich.edu $>$.

Johnson, Richard W., Amy J. Davidoff, and Kevin Perese. 2003. "Health Insurance Costs and Early Retirement Decisions.” Industrial and Labor Relations Review 56(4): 716-729.

Karoly, Lynn A. and Jeanette A. Rogowski. 1994. "The Effect of Access to PostRetirement Health Insurance on the Decisions to Retire Early." Industrial and Labor Relations Review 48 (October): 103-123.

Lazear, Edward P. 1998. Personnel Economics for Managers. New York, NY: Wiley. 
Madrian, Brigitte C. 2006. “The U.S. Health Care System and Labor Markets.” National Bureau of Economic Research Working Paper No. 11980, January.

. 1994. “The Effect of Health Insurance on Retirement.” Brookings Papers on Economic Activity (No. 1): 181-232.

Moon, Marilyn. 2005. "Retiree Health Coverage: Individuals Picking Up Bigger Tab.” TIAA-CREF Trends and Issues, July.

Olson, Craig A. 2000. "Part-time Work, Health Insurance Coverage, and the Wages of Married Women.” In Employee Benefits and Labor Markets in Canada and the United States. William T. Alpert and Stephen A. Woodbury, eds. Kalamazoo, MI: W.E. Upjohn Institute for Employment Research.

Rogowski, Jeannette and Lynn Karoly. 2000. "Health Insurance and Retirement Behavior: Evidence from the Health and Retirement Survey.” Journal of Health Economics 19(4): 529-539.

Rosen, Sherwin. 2000. “Does the Composition of Pay Matter?” In Employee Benefits and Labor Markets in Canada and the United States. William T. Alpert and Stephen A. Woodbury, eds. Kalamazoo, MI: W.E. Upjohn Institute for Employment Research.

Rust, John and Christopher Phelan. 1997. "How Social Security and Medicare Affect Retirement Behavior in a World of Incomplete Markets.” Econometrica 65(4): 781-831.

St. Clair, P., D. Blake, D. Bugliari, S. Chien, O. Hayden, M. Hurd, S. Ilchuk, F. Kung, A. Miu, C. Panis, P. Pantoja, A. Rastegar, S. Rohwedder, E. Roth, K. Wedell, and J. Zissimopoulos. 2006. RAND HRS Data Documentation, Version F. Santa Monica, CA: Labor and Population Program, RAND Center for the Study of Aging.

Schieber, Sylvester J. 2004. “The Outlook of Retiree Health Benefits.” TIAA-CREF Institute Research Dialogue, Issue No. 81, September.

United States Government Accountability Office. 2005. “Retiree Health Benefits: Options for Employment-Based Prescription Drug Benefits under the Medicare Modernization Act.” GAO Report to Congressional Committees, GAO-05-205.

Wellington, Alison J. and Deborah A. Cobb-Clark. 2000. “The Labor Supply Effects of Universal Coverage: What Can We Learn from Individuals with Spousal Coverage?” Research in Labor Economics 19(1): 315-344. 


\section{FIGURE 1}

Percentage of Private-Sector Establishments Offering Health Insurance to Retirees, 1997-2003

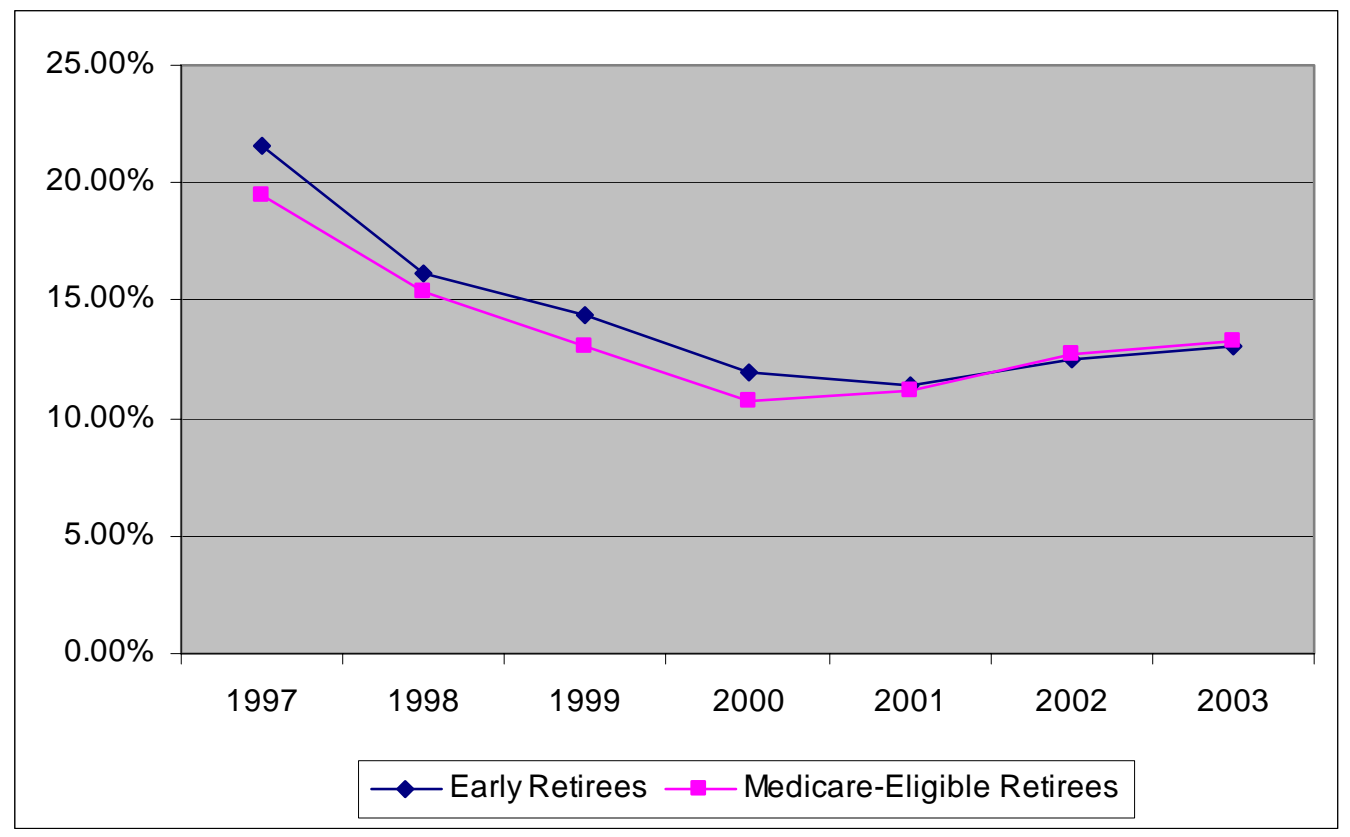

\section{FIGURE 2}

Percentage of Private-Sector Establishments with >1,000 Employees Offering Health Insurance to Retirees, 1997-2003

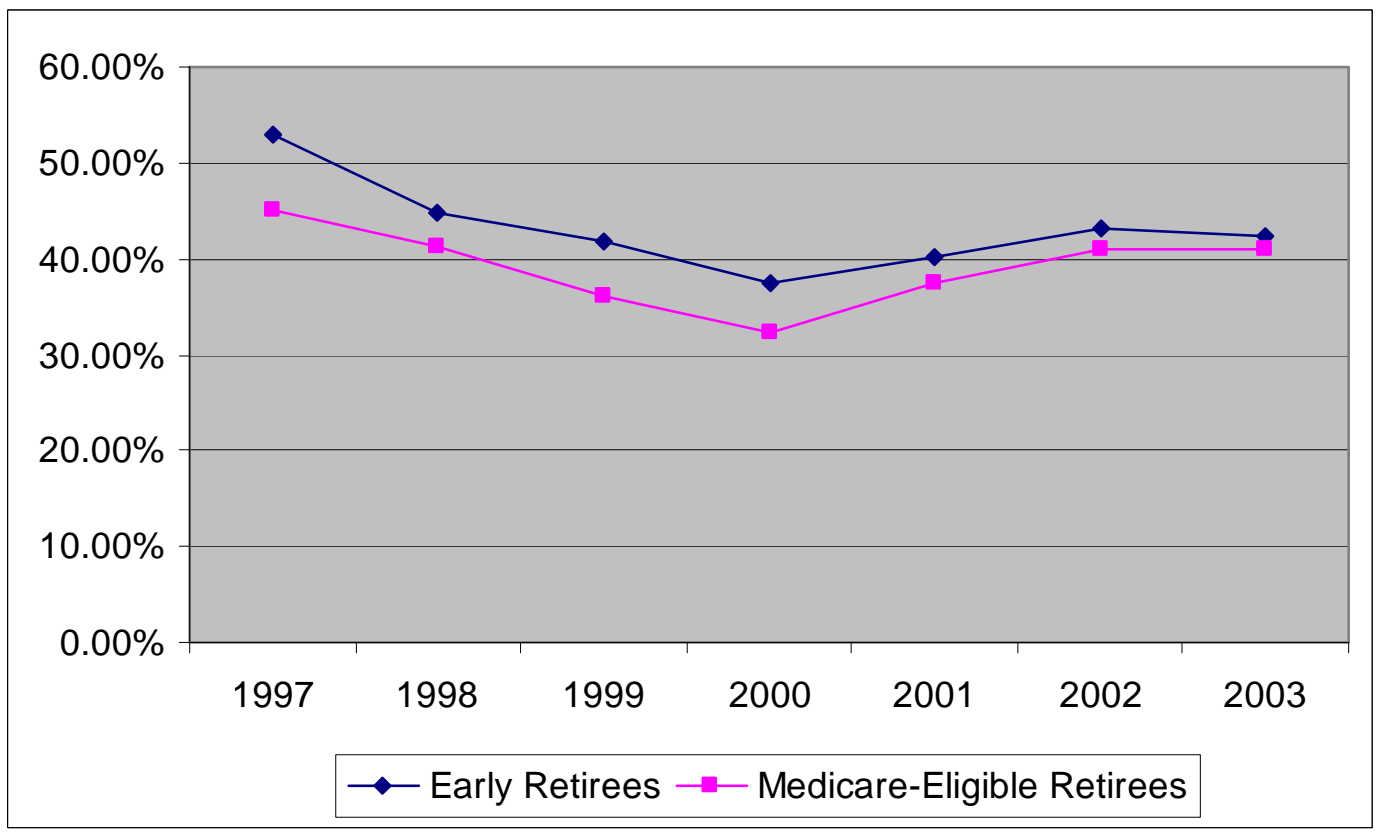




\section{FIGURE 3}

Percentage of Public-Sector Establishments Offering Health Insurance to Retirees, 19972003

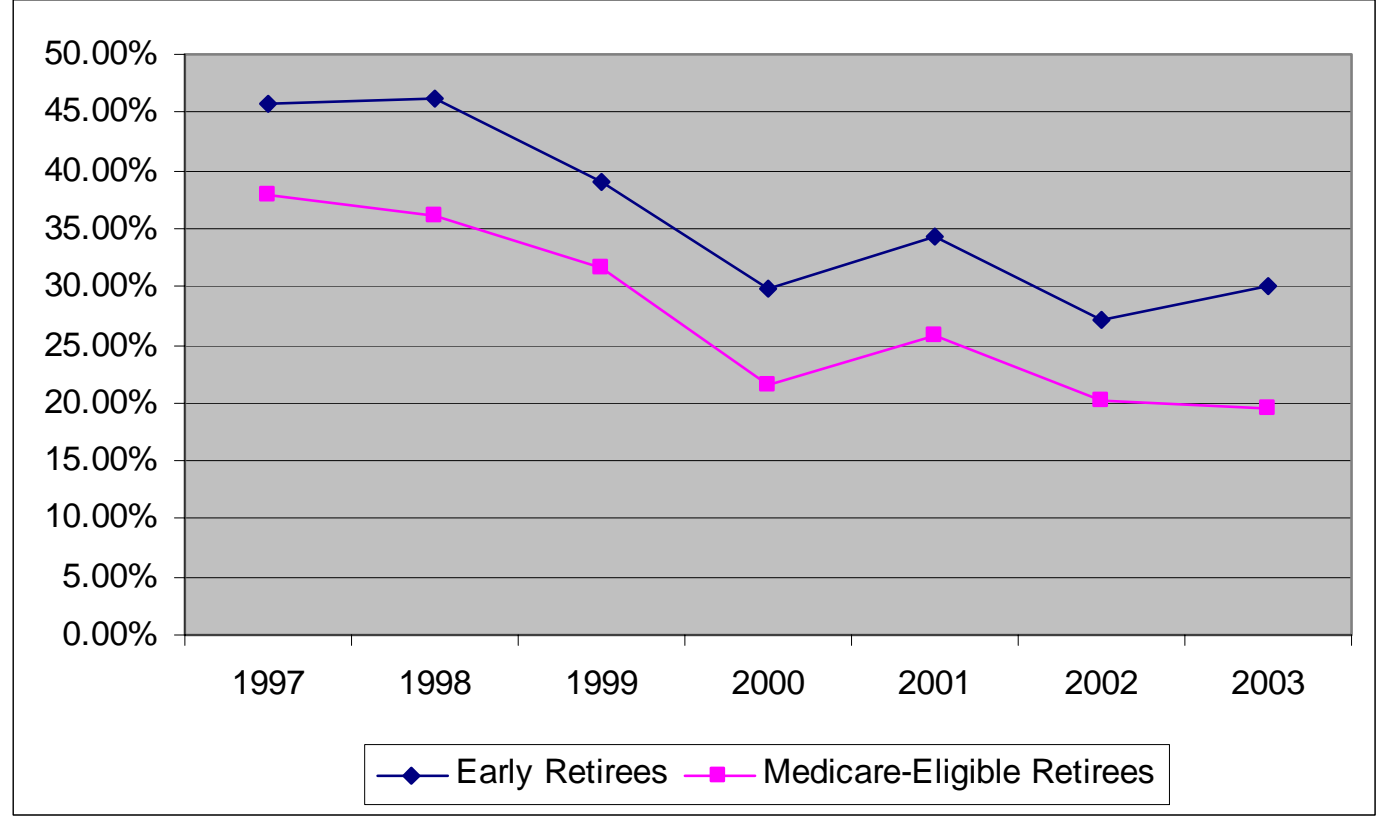

\section{FIGURE 4}

Percentage of State Government Establishments Offering Health Insurance to Retirees, 1997-2003

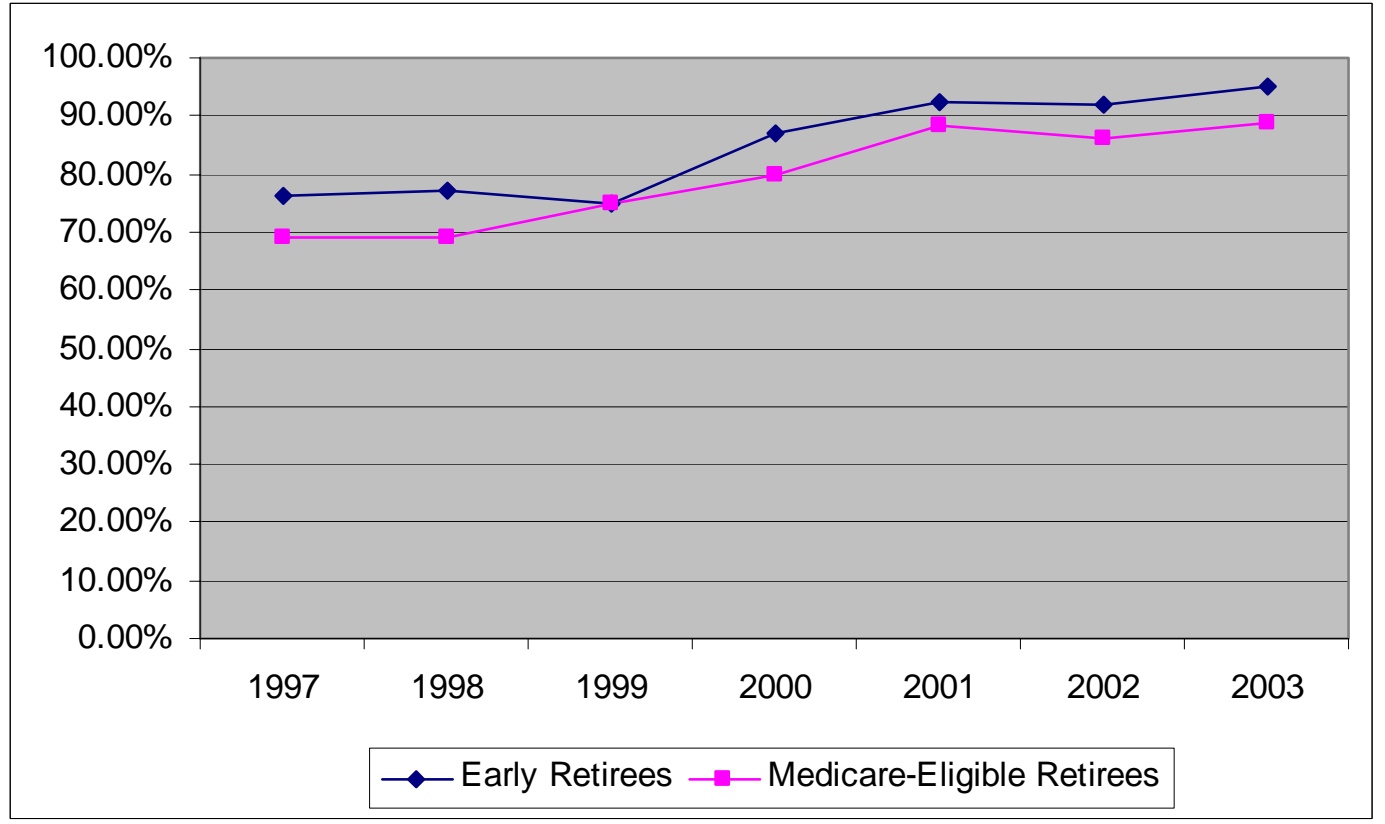


FIGURE 5

Transitions of Employed Full-Time Workers, Ages 51 to 61, With and Without Retiree Health Benefits, 1992 to 1994

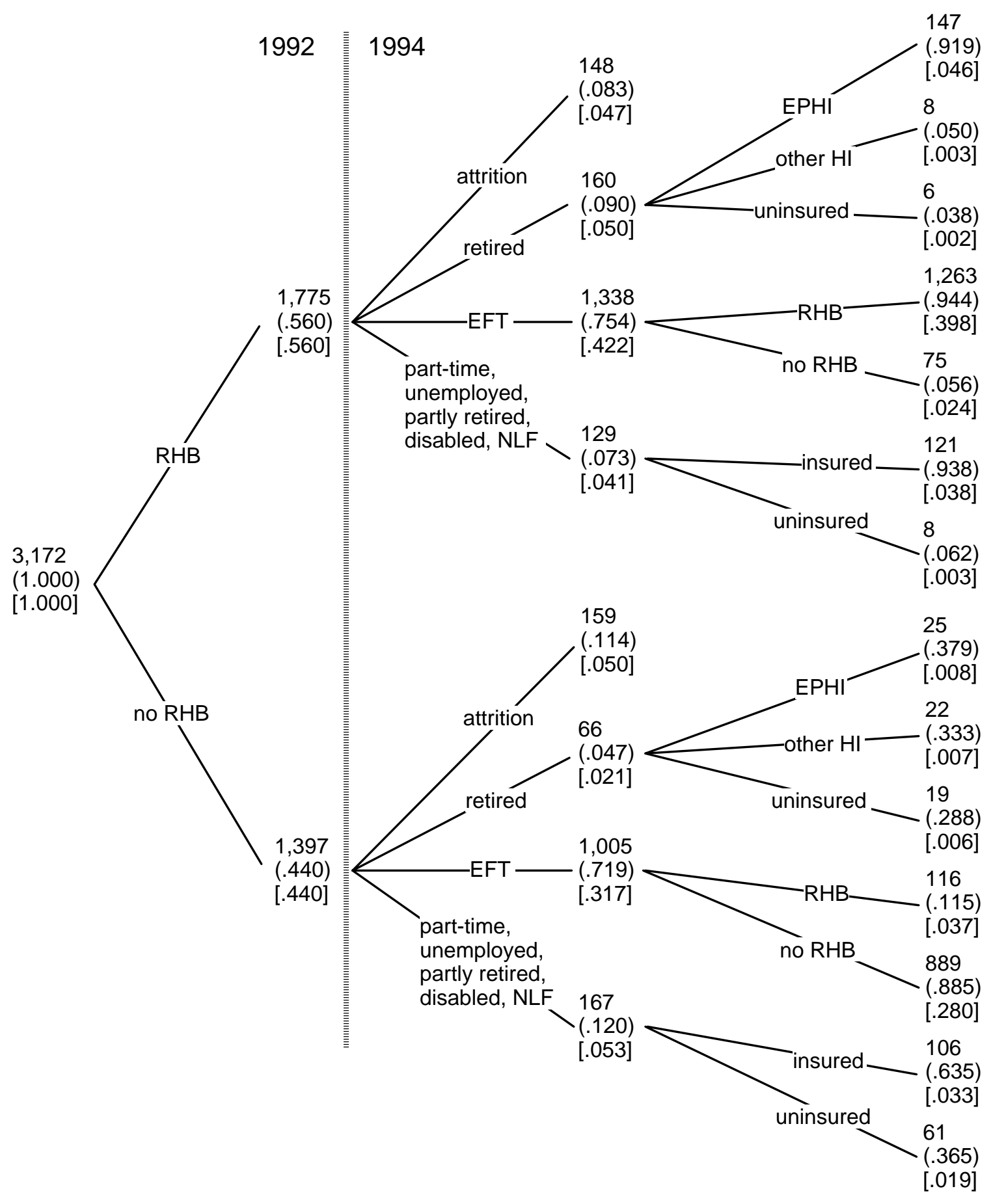


FIGURE 6

Transitions of Employed Full-Time Workers, Ages 51 to 61, With and Without Retiree Health Benefits, 1992 to 1996

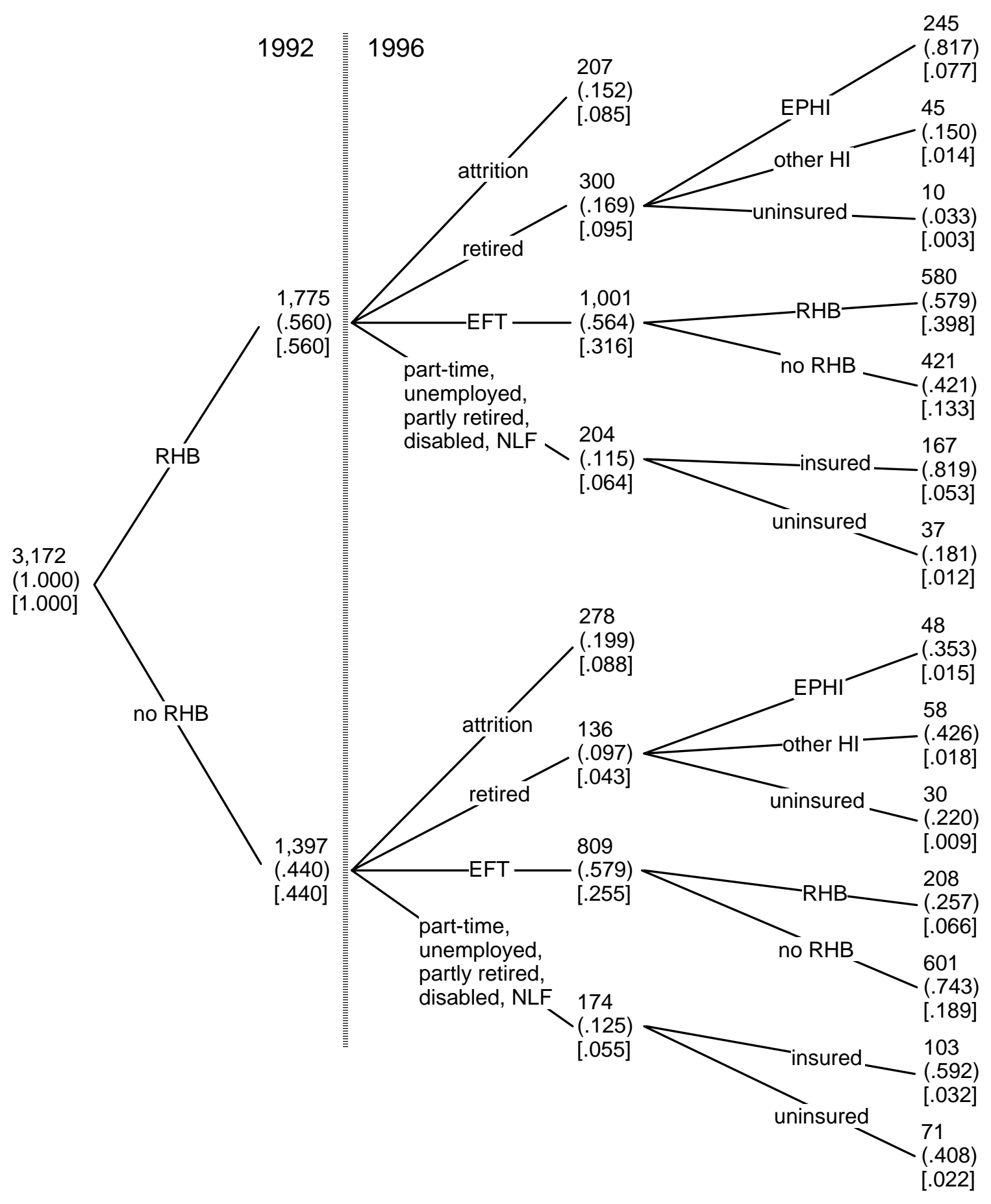




\section{Notes for Figures 5 and 6:}

Key to abbreviations:

RHB - covered by retiree health benefits

EFT - employed full-time

NLF — not in the labor force

EPHI - covered by employer-provided health insurance

other HI — covered by health insurance other than EPHI

Note: Each cell shows the individual raw count, the probability of being in a branch conditional on being in the previous branch (in parentheses), and the unconditional probability of being in that branch [in square brackets].

Source: Authors' tabulations of Health and Retirement Study data. See text for discussion. 
FIGURE 7

HRS Analysis Samples Illustrated

1992

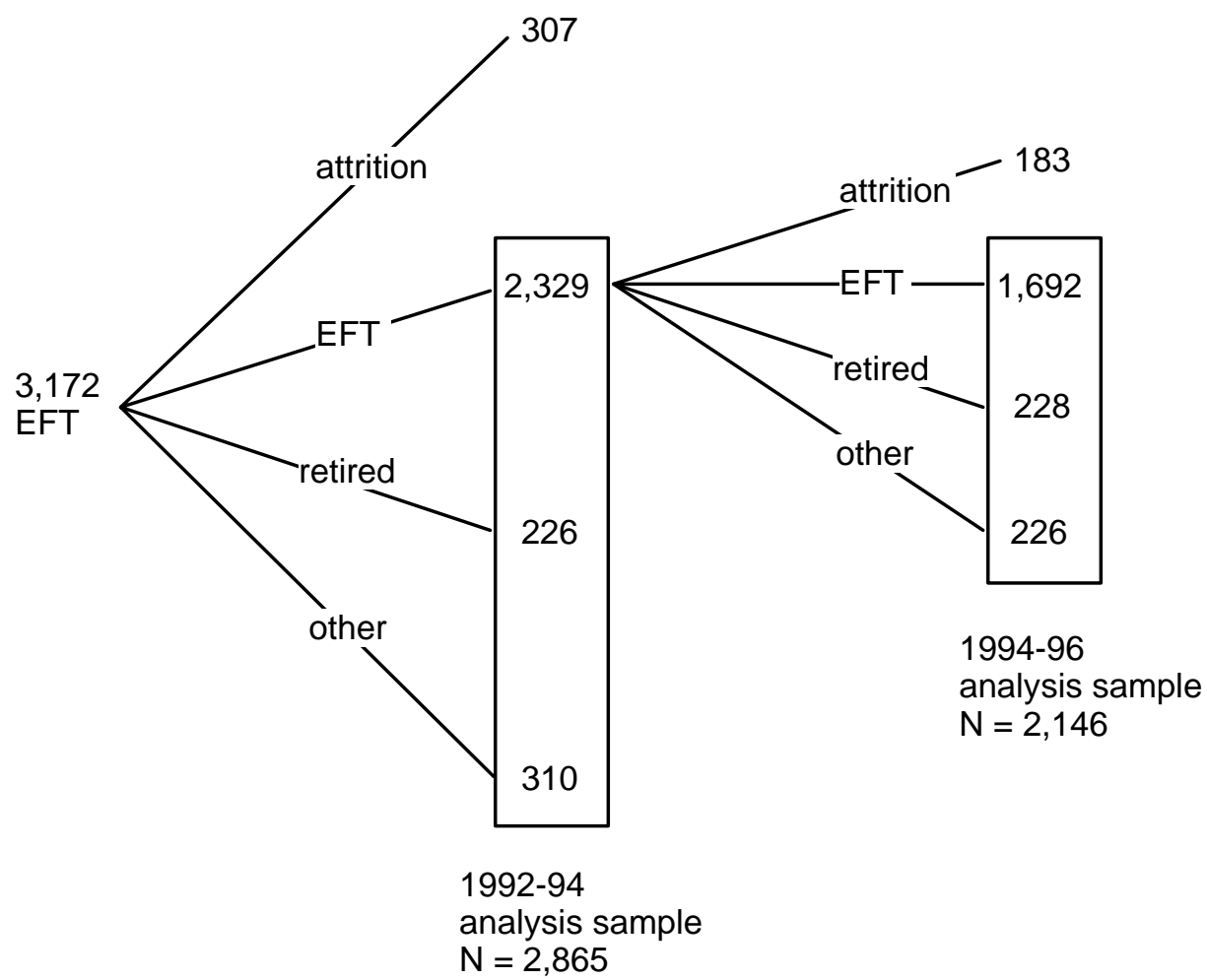

Notes:

EFT refers to employed full-time workers.

"Attrition" includes those who were not interviewed or died.

"Other" includes part-time, unemployed, disabled, and not in the labor force.

Source: Authors' tabulations of Health and Retirement Study data. See text for discussion. 
TABLE 1

Summary Statistics of Samples Used in Estimation (sample proportions, except where noted)

\begin{tabular}{|c|c|c|c|}
\hline Variable & $\begin{array}{l}\text { Starting sample: } \\
\text { (FT employed males } \\
\text { in 1992) }\end{array}$ & $\begin{array}{c}\text { 1992-1994 } \\
\text { transition sub-sample } \\
\text { (1992 values) }\end{array}$ & $\begin{array}{c}\text { 1994-1996 } \\
\text { transition sub-sample } \\
\text { (1994 values) }\end{array}$ \\
\hline \multirow{2}{*}{\multicolumn{4}{|c|}{$\begin{array}{l}\text { Retiree health benefits (RHB) } \\
\text { has employer-provided health } \\
\text { insurance (EHI) but no RHB } \\
\text { (ref) }\end{array}$}} \\
\hline & & & 0.25 \\
\hline has EHI and RHB & 0.56 & 0.57 & 0.60 \\
\hline no EHI but has other coverage & 0.08 & 0.08 & 0.07 \\
\hline no health insurance & 0.12 & 0.11 & 0.08 \\
\hline \multicolumn{4}{|l|}{ Pension } \\
\hline none or unknown (ref) & 0.39 & 0.38 & 0.34 \\
\hline has defined contribution & 0.18 & 0.18 & 0.20 \\
\hline has defined benefit & 0.25 & 0.25 & 0.33 \\
\hline has both & 0.17 & 0.18 & 0.12 \\
\hline has but type unknown & 0.01 & 0.01 & 0.01 \\
\hline \multicolumn{4}{|l|}{ Health status indicators } \\
\hline body mass index & 27 & 27 & 27 \\
\hline multiple chronic conditions & 0.20 & 0.20 & 0.23 \\
\hline reports fair or poor health & 0.12 & 0.12 & 0.12 \\
\hline \multicolumn{4}{|l|}{ Spousal labor supply } \\
\hline not married (ref) & 0.16 & 0.15 & 0.13 \\
\hline married, spouse works FT & 0.38 & 0.39 & 0.38 \\
\hline married, spouse works PT & 0.15 & 0.15 & 0.16 \\
\hline married, spouse not working & 0.31 & 0.31 & 0.33 \\
\hline Age at time of 1992 interview & 55.7 & 55.7 & 55.4 \\
\hline Nonwhite & 0.16 & 0.15 & 0.14 \\
\hline Years of schooling & 13 & 13 & 13 \\
\hline Months between interviews & N/A & 22 & 24 \\
\hline Sample size & 3,172 & 2,865 & 2,146 \\
\hline
\end{tabular}

Notes: The starting sample includes employed full-time men ages 51 to 61 in 1992 . The transition subsamples drop workers who had left the survey by 1994 or 1996. See Figure 7.

Source: Authors' tabulations of Health and Retirement Study data. See text for discussion. 
TABLE 2

Probit Estimates of Retirement Probability Between 1992-1994, 1994-1996, and 1992-1996, Full-Time Older Male Workers in the HRS (probit betas, with P-values and marginal effects)

\begin{tabular}{|c|c|c|c|c|c|c|c|c|c|c|c|c|}
\hline \multirow[b]{2}{*}{$\begin{array}{l}\text { Independent } \\
\text { Variable }\end{array}$} & \multicolumn{4}{|c|}{ 1992-1994 } & \multicolumn{4}{|c|}{ 1994-1996 } & \multicolumn{4}{|c|}{ 1992-1996 } \\
\hline & Probit $\beta$ & P-value & $\begin{array}{l}\text { Marginal } \\
\text { effect (\%) }\end{array}$ & $\begin{array}{c}\text { M.E./base } \\
(\%)\end{array}$ & Probit $\beta$ & P-value & $\begin{array}{l}\text { Marginal } \\
\text { effect (\%) }\end{array}$ & $\begin{array}{c}\text { M.E./base } \\
(\%)\end{array}$ & Probit $\beta$ & P-value & $\begin{array}{l}\text { Marginal } \\
\text { effect (\%) }\end{array}$ & $\begin{array}{c}\text { M.E./base } \\
(\%)\end{array}$ \\
\hline \multicolumn{13}{|l|}{$\begin{array}{l}\text { Retiree health benefits(RHB) } \\
\text { [ref: has employer- } \\
\text { provided health insurance } \\
\text { (EHI) but no RHB] }\end{array}$} \\
\hline has $\mathrm{EHI}$ and RHB & 0.39 & 0.00 & 4 & 55 & 0.24 & 0.01 & 3 & 29 & 0.33 & 0.00 & 7 & 41 \\
\hline $\begin{array}{l}\text { no EHI but has other } \\
\text { coverage }\end{array}$ & 0.38 & 0.02 & 6 & 70 & 0.16 & 0.40 & 2 & 22 & 0.23 & 0.12 & 5 & 32 \\
\hline no health insurance & 0.19 & 0.24 & 2 & 31 & -0.18 & 0.39 & -2 & -20 & 0.11 & 0.43 & 2 & 14 \\
\hline \multicolumn{13}{|l|}{$\begin{array}{l}\text { Pension } \\
\text { (ref: none or unknown) }\end{array}$} \\
\hline has defined contribution & 0.02 & 0.86 & 0 & 3 & 0.06 & 0.64 & 1 & 8 & 0.16 & 0.12 & 3 & 21 \\
\hline has defined benefit & 0.35 & 0.00 & 5 & 58 & 0.68 & 0.00 & 11 & 101 & 0.48 & 0.00 & 11 & 68 \\
\hline has both & 0.28 & 0.02 & 4 & 47 & 0.47 & 0.00 & 8 & 76 & 0.52 & 0.00 & 13 & 78 \\
\hline has but type unknown & -0.15 & 0.75 & -2 & -19 & 0.70 & 0.10 & 15 & 139 & 0.71 & 0.02 & 20 & 124 \\
\hline \multicolumn{13}{|l|}{ Health status indicators } \\
\hline body mass index & 0.01 & 0.11 & 0 & 2 & 0.01 & 0.25 & 0 & 1 & 0.01 & 0.17 & 0 & 1 \\
\hline multiple chronic conditions & 0.19 & 0.03 & 2 & 30 & -0.02 & 0.85 & 0 & -2 & 0.11 & 0.16 & 2 & 14 \\
\hline reports fair or poor health & 0.20 & 0.07 & 3 & 33 & 0.39 & 0.00 & 7 & 61 & 0.31 & 0.00 & 7 & 45 \\
\hline \multicolumn{13}{|l|}{$\begin{array}{l}\text { Spousal labor supply } \\
\text { (ref: not married) }\end{array}$} \\
\hline married, spouse works FT & -0.44 & 0.00 & -5 & -60 & -0.29 & 0.03 & -4 & -34 & -0.23 & 0.02 & -5 & -28 \\
\hline married, spouse works PT & -0.56 & 0.00 & -5 & -60 & -0.17 & 0.26 & -2 & -19 & -0.19 & 0.09 & -4 & -23 \\
\hline married, spouse not working & g -0.32 & 0.00 & -3 & -42 & -0.08 & 0.54 & -1 & -9 & -0.18 & 0.06 & -4 & -22 \\
\hline Age in 1992 & 0.12 & 0.00 & 1 & 17 & 0.16 & 0.00 & 2 & 20 & 0.16 & 0.00 & 3 & 20 \\
\hline Nonwhite & -0.07 & 0.54 & -1 & -9 & -0.07 & 0.54 & -1 & -8 & -0.05 & 0.58 & -1 & -6 \\
\hline Years of schooling & 0.00 & 0.82 & $\overline{0}$ & 0 & -0.04 & 0.00 & -1 & -5 & -0.04 & 0.00 & -1 & -5 \\
\hline Months between interviews & 0.01 & 0.44 & 0 & 2 & 0.01 & 0.75 & 0 & 1 & 0.00 & 0.80 & 0 & 0 \\
\hline Intercept & -9.08 & 0.00 & & & -10.81 & 0.00 & & & -9.93 & 0.00 & & \\
\hline
\end{tabular}


Log likelihood

Sample size

Number retired

Percent retired

Left survey (all reasons) 